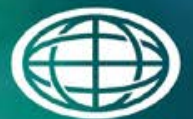

Savannah River

National Laboratory ${ }^{m}$

OPERATED BY SAVANNAH RIVER NUCLEAR SOLUTIONS

\title{
Saltstone 4QCY13 TCLP Results
}

D. H. Miller

April 3, 2014

SRNL-STI-2014-00149, Revision 0 
SRNL-STI-2014-00149

Revision 0

\section{DISCLAIMER}

This work was prepared under an agreement with and funded by the U.S. Government. Neither the U.S. Government or its employees, nor any of its contractors, subcontractors or their employees, makes any express or implied:

1. warranty or assumes any legal liability for the accuracy, completeness, or for the use or results of such use of any information, product, or process disclosed; or

2. representation that such use or results of such use would not infringe privately owned rights; or

3. endorsement or recommendation of any specifically identified commercial product, process, or service.

Any views and opinions of authors expressed in this work do not necessarily state or reflect those of the United States Government, or its contractors, or subcontractors.

\section{Printed in the United States of America \\ Prepared for U.S. Department of Energy}


SRNL-STI-2014-00149

Revision 0

Keywords: Saltstone

Regulatory

TCLP

Retention: Permanent

\section{Saltstone 4QCY13 TCLP Results}

D. H. Miller

April 3, 2014

Prepared for the U.S. Department of Energy under contract number DE-AC09-08SR22470.

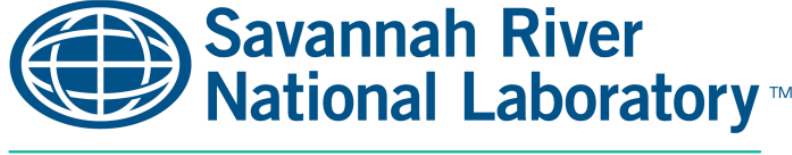

OPERATED BY SAVANNAH RIVER NUCLEAR SOLUTIONS 


\section{REVIEWS AND APPROVALS}

\section{AUTHORS:}

D. H. Miller, Engineering Process Development

Date

TECHNICAL REVIEW:

J. M . Pareizs, Process Technology Programs

Date

APPROVAL:

E. N. Hoffman, Manager

Date

Engineering Process Development

S. L. Marra, Manager

Date

Environmental \& Chemical Process Technology Research Programs

E. J. Freed, Manager

Date

DWPF and Saltstone Facility Engineering 


\section{EXECUTIVE SUMMARY}

A Saltstone waste form was prepared in the Savannah River National Laboratory (SRNL) from a Tank $50 \mathrm{H}$ sample and Z-Area premix material for the fourth quarter of calendar year 2013 (4QCY13). After a 62 day cure, samples of the saltstone were collected, and the waste form was shown to meet the South Carolina Hazardous Waste Management Regulations (SCHWMR) R.61-79.261.24 and R.61-79.268.48(a) requirements for a nonhazardous waste form with respect to RCRA metals and underlying hazardous constituents. These analyses met all quality assurance specifications of USEPA SW-846. 


\section{TABLE OF CONTENTS}

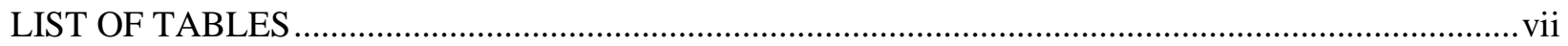

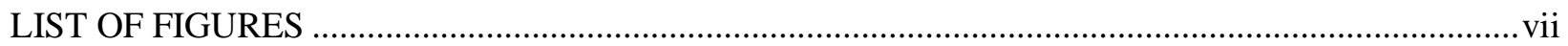

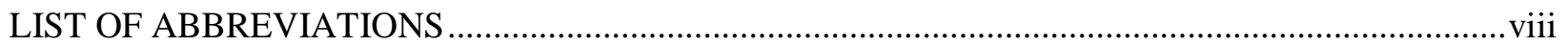

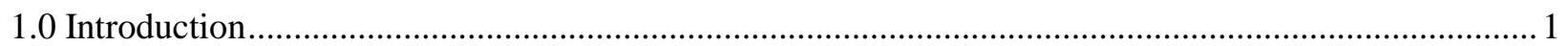

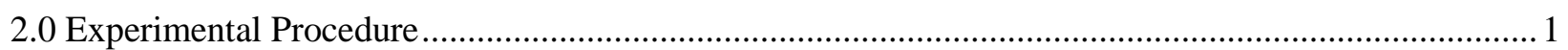

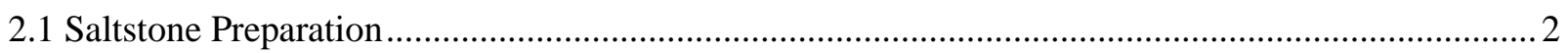

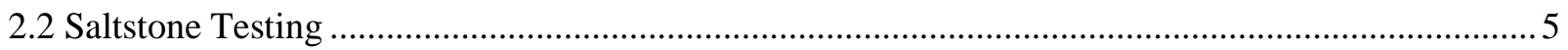

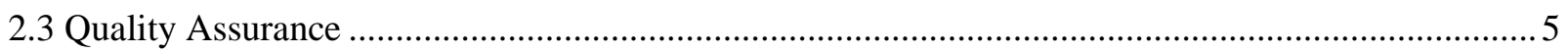

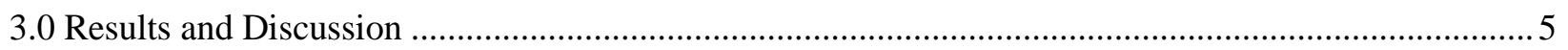

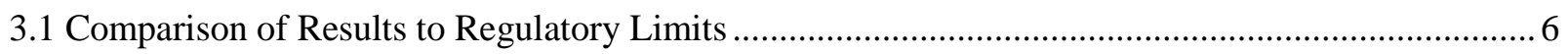

3.2 Analytical Quality Control .............................................................................................. 7

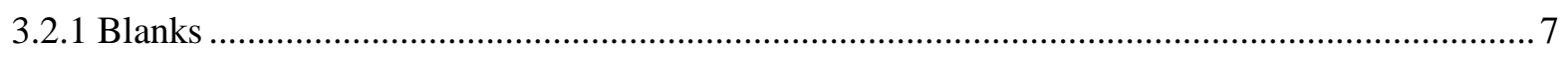

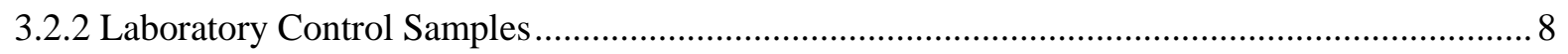

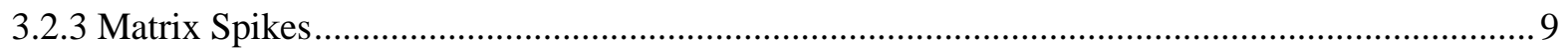

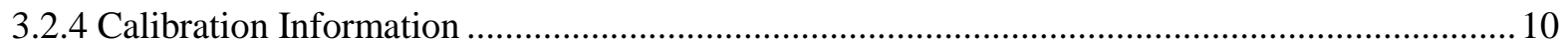

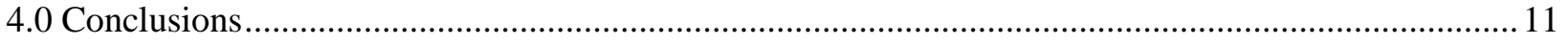

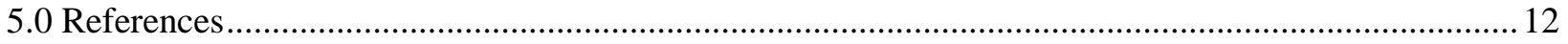




\section{LIST OF TABLES}

Table 2-1. Sample Results of TCLP Metals and UHCs from Tank 50 WAC Analyses ............................. 3

Table 2-2. Customer Recommended Values for Preparation of TCLP Sample......................................... 3

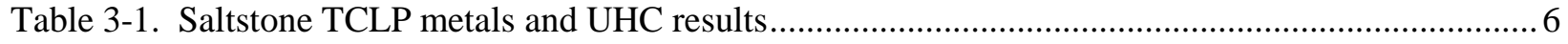

Table 3-2. Saltstone TCLP and UHC Results and Corresponding Regulatory Limits ............................ 7

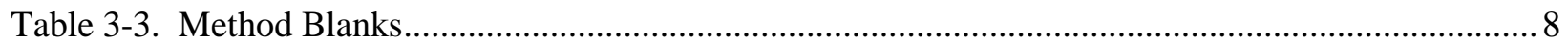

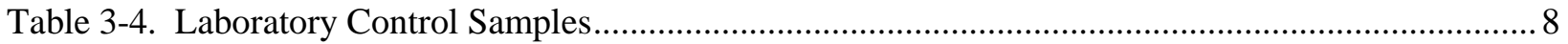

Table 3-5. Matrix Spike and Matrix Spike Duplicate Results .............................................................. 9

Table 3-6. Duplicates and Relative Percent Difference ........................................................................ 10

\section{LIST OF FIGURES}

Figure 2-1. Flowchart of Saltstone Preparation and Analysis.............................................................. 2

Figure 2-2. Data Sheet for saltstone mix used to prepare the 4QCY13 TCLP sample ............................... 4 


\section{LIST OF ABBREVIATIONS}

\begin{tabular}{ll} 
ARP & Actinide Removal Process \\
CVAA & Cold Vapor Atomic Absorption \\
DSS-HT & Decontaminated Salt Solution Hold Tank \\
ESS-WP & Environmental Services Section - Waste Programs \\
ETP & Effluent Treatment Project \\
ICP-AES & Inductively Coupled Plasma - Atomic Emission Spectroscopy \\
ISWLF & Industrial Solid Waste Landfill \\
LCS & Laboratory Control Sample \\
MCL & Maximum Contaminant Level \\
MCU & Modular Caustic Side Solvent Extraction Unit \\
MS & Matrix Spike \\
MSD & Matrix Spike Duplicate \\
RCRA & Resource Conservation and Recovery Act \\
RL & Reporting Limit \\
RPD & Relative Percent Differences \\
SCDHEC & South Carolina Department of Health and Environmental Control \\
SCHWMR & South Carolina Hazardous Waste Management Regulations \\
SDF & Saltstone Disposal Facility \\
SDG & Sample Delivery Group \\
SPF & Saltstone Production Facility \\
SWLF & Solid Waste LandFill \\
SWRI & Southwest Research Institute \\
SRNL & Savannah River National Laboratory \\
TCLP & Toxic Characteristic Leaching Procedure \\
UHC & Underlying Hazardous Constituent \\
UTS & Universal Treatment Standards \\
USEPA & United State Environmental Protection Agency \\
WAC & Waste Acceptance Criteria \\
\hline
\end{tabular}




\subsection{Introduction}

The Saltstone Production Facility (SPF) receives waste from Tank $50 \mathrm{H}$ for treatment. In the fourth quarter of the 2013 calendar year (4QCY13), Tank 50H accepted transfers of approximately 1.4 kgal from the Effluent Treatment Project (ETP), approximately 4.6 kgal from $211 \mathrm{H}$, and approximately $16.6 \mathrm{kgal}$ from the Actinide Removal Process / Modular Caustic Side Solvent Extraction Unit (ARP/MCU) Decontaminated Salt Solution Hold Tank (DSS-HT). ${ }^{1}$

The Saltstone Grout Sampling plan provides the South Carolina Department of Health and Environmental Control (SCDHEC) with the chemical and physical characterization strategy for the salt solution which is to be disposed of in the Z-Area Solid Waste Landfill (SWLF). ${ }^{2}$ During operation, samples were collected from Tank $50 \mathrm{H}$ and grout samples prepared to determine the non-hazardous nature of the grout to meet the requirements of the South Carolina Hazardous Waste Management Regulations (SCHWMR) R.61-79.261.24(b) and R.61-79.268.48(a). ${ }^{3}$

Savannah River National Laboratory (SRNL) was requested ${ }^{4}$ to prepare saltstone from samples of Tank 50H obtained October 29, 2013 during 4QCY13 to determine the non-hazardous nature of the grout. The samples were cured and shipped to Southwest Research Institute (SWRI) to perform the Toxic Characteristic Leaching Procedure (TCLP) ${ }^{5}$ and subsequent extract analysis on saltstone samples for the analytes required for the quarterly analysis saltstone sample. In addition to the eight toxic metals-arsenic, barium, cadmium, chromium, mercury, lead, selenium and silver-analytes include underlying hazardous constituents (UHC) antimony, beryllium, nickel, thallium, benzene, phenols, and total and amenable cyanide which could not be eliminated from analysis by process knowledge. ${ }^{6}$

\subsection{Experimental Procedure}

This section is a summary of the approach taken to prepare and characterize the saltstone samples. The saltstone sample preparation was performed at SRNL. Saltstone sample characterization was performed at SWRI in San Antonio, Texas. Figure 2-1 is a flowchart of the steps taken to prepare and characterize the saltstone samples. 


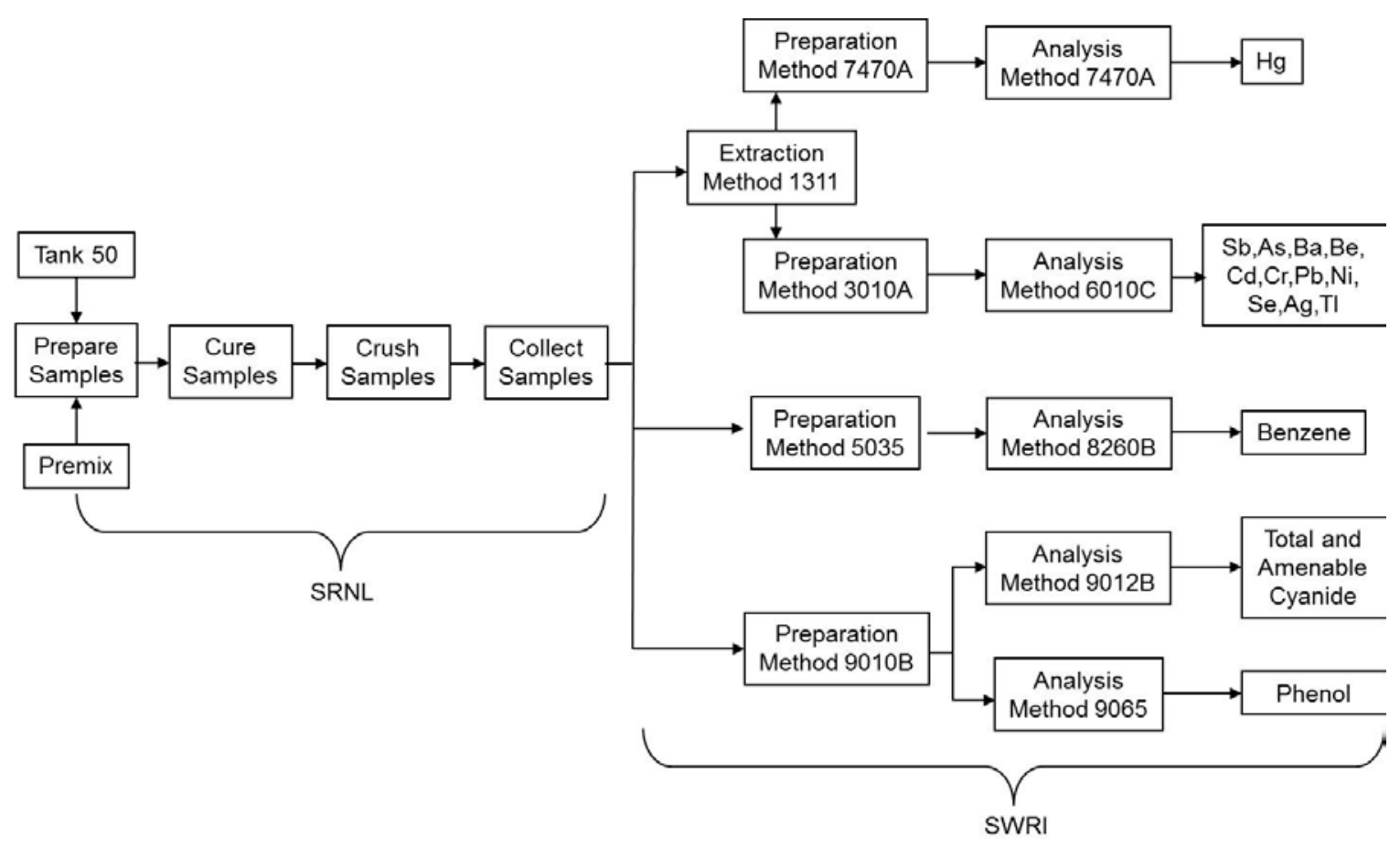

Figure 2-1. Flowchart of Saltstone Preparation and Analysis

\subsection{Saltstone Preparation}

Saltstone preparation was performed at SRNL. The weight percent solids data used for the TCLP sample was taken from the quarterly Waste Acceptance Criteria (WAC) analyses performed on Tank $50 \mathrm{H}^{7}$. Table 2-1 lists the concentration of TCLP metals of interest in the salt solution from the WAC analysis for the sample. ${ }^{7}$ As shown in Table 2-1 the contents of Tank $50 \mathrm{H}$ exceed the regulatory limits for antimony, cadmium, chromium, mercury, nickel, and phenol, and therefore must be treated and disposed of in a non-hazardous waste form. Table 2-2 contains the parameters used to prepare the TCLP sample. ${ }^{1}$

Saltstone samples for TCLP were prepared with the Tank $50 \mathrm{H}$ blended salt solution and a premix of cement, slag, and fly ash. Figure 2-2 shows the formulation used to prepare these samples. The admixtures were added to the salt solution first and then the dry feeds were added to the liquid. The salt solution, admixtures and premix materials were mixed for approximately three minutes using a paddle blade mixer. The mixing was paused for approximately five seconds after 30 seconds of mixing to allow entrained air to escape from the grout. After the saltstone slurry was mixed, it was cast into a polyethylene zip top bag. The bag was laid flat and the air was expelled prior to sealing. The sample was cured flat in a polypropylene bag to facilitate the size reduction step needed to conform to the particle size requirements of the TCLP method.

After curing for not less than 28 days $^{2}-63$ days for the 4QCY13 sample, the saltstone was removed from the container and a portion of the saltstone was crushed to particles less than 0.9 centimeters (3/8 inch) as prescribed by Section 7.13 of the TCLP method. The crushed saltstone was packaged into containers provided by Environmental Services Section - Waste Programs (ESS-WP). After the saltstone has been crushed, sieved and packaged, the sample is deemed "collected." 2 ESS-WP retrieved the sample from SRNL and transported them to SWRI for extraction and analysis. 
Table 2-1. Sample Results of TCLP Metals and UHCs from Tank 50 WAC Analyses

\begin{tabular}{|c|c|c|}
\hline \multirow[t]{2}{*}{ Analyte } & $\begin{array}{c}\text { Sample Results } \\
(\mathrm{mg} / \mathrm{L})^{7}\end{array}$ & $\begin{array}{c}\text { Regulatory Limits } \\
\text { (mg/L) }\end{array}$ \\
\hline & $4 \mathrm{Q} 13$ & Toxicity $^{\text {a }}$ \\
\hline As & $<0.091$ & 5 \\
\hline Ba & $<1.16$ & 100 \\
\hline Cd & $<2.31$ & 1 \\
\hline $\mathrm{Cr}$ & 34.4 & 5 \\
\hline $\mathbf{P b}$ & 0.226 & 5 \\
\hline Hg & 63.0 & 0.2 \\
\hline Se & $<0.182$ & 1 \\
\hline Ag & $<2.24$ & 5 \\
\hline-- & & $\mathrm{UHC}^{\mathrm{b}}$ \\
\hline Sb & 26.8 & 1.15 \\
\hline $\mathbf{B e}$ & $<0.166$ & 1.22 \\
\hline $\mathbf{N i}$ & $<19.8$ & 11 \\
\hline $\mathbf{T l}$ & $<0.112$ & 0.20 \\
\hline- & (mg/kg) & (mg/kg) \\
\hline benzene & $<0.121$ & 10 \\
\hline phenol & $<8.07$ & 6.2 \\
\hline cyanide (total) & NM & 590 \\
\hline cyanide (amenable) & NM & 30 \\
\hline
\end{tabular}

NM - Not Measured

a SCHWMR R.61-79.261.24(b) "Characteristic of Toxicity.”

b SCHWMR R.61-79.268.48 "Universal Treatment Standards.”

Table 2-2. Customer Recommended Values for Preparation of TCLP Sample

\begin{tabular}{|c|c|}
\hline Parameter & 4QCY13 \\
\hline \hline Water-to-Premix ratio & 0.59 \\
\hline $\begin{array}{c}\text { (Daratard 17) gal/Ton premix } \\
\text { premix }\end{array}$ & 0 \\
\hline $\begin{array}{c}\text { (Dow Corning Q2-3183A) gal/Ton } \\
\text { premix }\end{array}$ & 0.20 \\
\hline
\end{tabular}


Saltstone Mix Data Sheet

\begin{tabular}{|c|c|c|c|}
\hline \multicolumn{2}{|l|}{ MIX \#0148 } & \multicolumn{2}{|c|}{ Date: $11 / 13 / 2013$} \\
\hline Material & $\%$ & $W T \%$ & Grams \\
\hline Waste Solution: Tank 50 10/29/13 4013 & & \multirow{3}{*}{45.19} & \multirow{3}{*}{250.02} \\
\hline Wt\% Solids \# 20.425 & & & \\
\hline Grams Water 17B.95 & & & \\
\hline Admlxwre: B2Antifoam & & 0.08 & 0.24 \\
\hline Admixture: & & & 0.00 \\
\hline \multicolumn{4}{|l|}{ Admixture: } \\
\hline Premlx & & 54.77 & 303.00 \\
\hline Cement (\% of Prembx) & 10 & $5.4 \mathrm{~B}$ & 30.30 \\
\hline Slag ( $\%$ of Premix) & 45 & 24.64 & 136.35 \\
\hline Fly Ash (\% of Premlx) & 45 & 24.64 & 136,35 \\
\hline Total & 100 & 100.04 & 553.26 \\
\hline Water to Premix Ratio & \multicolumn{2}{|c|}{0.59} & \\
\hline \multicolumn{4}{|l|}{$\begin{array}{l}\text { From customer: } \\
0.59 \text { WiP } \\
0.10 \mathrm{gpm} \text { Antiloam } \\
33 \mathrm{TPH} \text { Dy Feeds } \\
\text { NO Daratard }\end{array}$} \\
\hline \multicolumn{4}{|c|}{ 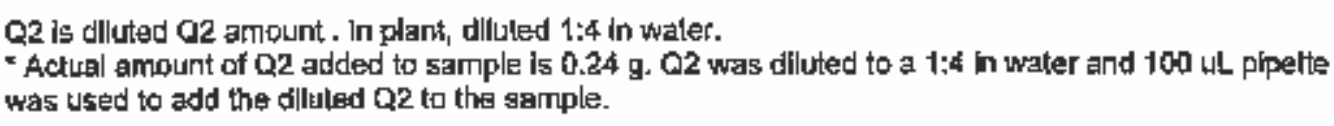 } \\
\hline
\end{tabular}

Figure 2-2. Data Sheet for saltstone mix used to prepare the 4QCY13 TCLP sample 


\subsection{Saltstone Testing}

Saltstone testing was performed by SWRI. Activities associated with the 4QCY13 saltstone sample were TCLP extraction, TCLP leachate digestion and analysis, extraction of solid subsamples and extract analysis. The sample arrived at SWRI in San Antonio, Texas on January 27, 2014 for analysis. The samples were delivered with proper chain of custody documentation and signatures. All sample containers arrived without any visible signs of tampering or breakage. Delivery was delayed over the weekend which caused the samples to arrive on Monday rather than Friday. This resulted in an elevated sample temperature as noted in the SWRI report ${ }^{8}$.

The volatile compound, benzene, was prepared by SW-846 Method 5035 and analyzed according to SW-846 Method 8260B. For total and amenable cyanide, the sample was prepared using SW$8469010 \mathrm{~B}$ and analyzed using method 9012B. For total phenol, since the sample is a solid, method SW-846 9065 (Phenolics), a manual distillation and colorimetric procedure, was performed.

For the TCLP metals analysis, the sample was extracted by SW-846 method 1311. It is reported from method 1311 "modified" since a reduced sample mass was extracted due to its elevated sample activity. The extracts were prepared and analyzed for mercury by SW-846 Method 7470A. The extracts were digested according to SW-846 Method 3010A for the remaining metals. Those digestates were analyzed by ICP-AES, SW-846 Method 6010C.

\subsection{Quality Assurance}

Requirements for performing reviews of technical reports and the extent of review are established in manual E.7 2.60. SRNL documents the extent and type of review using the SRNL Technical Report Design Checklist contained in WSRC-IM-2002-00011, Rev. 2.

\subsection{Results and Discussion}

Results summarized in the following tables are from the data package for these analyses. ${ }^{8}$ Data is presented in these results as reported by the vendor, SWRI. Analytes that were analyzed for, but not detected, have been flagged with the "U" qualifier. This is based on necessary concentration dilution action and not necessarily the instrument detection limit. Analytes flagged with a "J" qualifier indicate an issue with the matrix spike recoveries. Post digestion spike recoveries were performed for these analytes as confirmation of results. In addition to the results, the reporting limit for each analyte has been given. The reporting limit (RL) is the lowest level at which an analyte may be accurately and reproducibly measured.

Results in Table 3-1, when compared with the RL, can be organized into three groups:

- Barium, silver, amenable and total cyanide, and phenol are flagged as having matrix spike issues.

- Cadmium, chromium, lead, mercury, selenium, silver, antimony, nickel, thallium, beryllium, benzene, and total phenol were detected at or below the RLs.

- Arsenic, barium, amenable and total cyanide were detected in the leachates at concentrations above the RLs. 
Table 3-1. Saltstone TCLP metals and UHC results

\begin{tabular}{|c|c|c|c|c|c|}
\hline Analyte & Results & $\mathbf{Q}^{*}$ & $\begin{array}{c}\text { Reporting } \\
\text { Limit }\end{array}$ & Units & Method \\
\hline Arsenic & 39.3 & 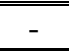 & 10.0 & 르/L (TCLP) & 1311/6010C \\
\hline Barium & 794 & $\mathrm{~J}$ & 5.0 & $\mu \mathrm{g} / \mathrm{L}$ (TCLP) & 1311/6010C \\
\hline Cadmium & 5.0 & $\mathrm{U}$ & 5.0 & $\mu \mathrm{g} / \mathrm{L}$ (TCLP) & 1311/6010C \\
\hline Chromium & 5.0 & $\mathrm{U}$ & 5.0 & $\mu \mathrm{g} / \mathrm{L}$ (TCLP) & 1311/6010C \\
\hline Lead & 5.0 & $\mathrm{U}$ & 5.0 & $\mu \mathrm{g} / \mathrm{L}$ (TCLP) & 1311/6010C \\
\hline Mercury & 0.2 & $\bar{U}$ & 0.2 & $\mu \mathrm{g} / \mathrm{L}$ (TCLP) & $1311 / 7470 \mathrm{~A}$ \\
\hline Selenium & 10.0 & $\mathrm{U}$ & 10.0 & $\mu \mathrm{g} / \mathrm{L}(\mathrm{TCLP})$ & 1311/6010C \\
\hline Silver & 5.0 & UJ & 5.0 & $\mu \mathrm{g} / \mathrm{L}$ (TCLP) & 1311/6010C \\
\hline Antimony & 20.0 & $\mathrm{U}$ & 20.0 & $\mu \mathrm{g} / \mathrm{L}$ (TCLP) & 1311/6010C \\
\hline Nickel & 5.0 & $\mathrm{U}$ & 5.0 & $\mu \mathrm{g} / \mathrm{L}$ (TCLP) & 1311/6010C \\
\hline Thallium & 20.0 & $\mathrm{U}$ & 20.0 & $\mu \mathrm{g} / \mathrm{L}$ (TCLP) & 1311/6010C \\
\hline Beryllium & 5.0 & $\mathrm{U}$ & 5.0 & $\mu \mathrm{g} / \mathrm{L}$ (TCLP) & 1311/6010C \\
\hline Benzene & 1.1 & $\mathrm{U}$ & 1.1 & $\mu \mathrm{g} / \mathrm{kg}$ & EPA $8260 B$ \\
\hline Amenable Cyanide & 1.17 & $\mathrm{~J}$ & 0.490 & $\mathrm{mg} / \mathrm{kg}$ & EPA 9012B \\
\hline Total Cyanide & 1.17 & $\mathrm{~J}$ & 0.490 & $\mathrm{mg} / \mathrm{kg}$ & EPA 9012B \\
\hline Total Phenol & 0.991 & UJ & 0.991 & $\mathrm{mg} / \mathrm{kg}$ & EPA 9065 \\
\hline
\end{tabular}

- Indicates a location in the table for which an entry would not be appropriate.

*Q = Qualifier Column

$\mathrm{U}=$ Indicates compound was analyzed for, but not detected.

$\mathrm{J}=$ Indicates MS/MSD recoveries were not within specification

\subsection{Comparison of Results to Regulatory Limits}

Results from the TCLP leachate analyses from Table 3-1 are replicated in Table 3-2; however the TCLP metals units are changed from $\mu \mathrm{g} / \mathrm{L}$ to $\mathrm{mg} / \mathrm{L}$ and compared to the regulatory limits that may be applied to the Saltstone waste form. Table 3-2 includes the SCHWMR R.61-79.261.24(b) limits above which a waste is to be considered characteristically hazardous for toxicity and the SCHWMR R.61-79.268.48 Universal Treatment Standards (UTS) for hazardous constituents. In addition, Maximum Contaminant Levels (MCL's) from the State Primary Drinking Water Regulations $^{2}$ also have been included in Table 3-2. By comparing the sample results and the regulatory limits the following conclusions can be made:

- The saltstone waste form was not characteristically hazardous for toxicity.

- The leachate metals concentrations were below the Nonwastewater Standard for all of the metals and UHCs.

- Barium, chromium, lead, mercury, selenium, and silver were below the MCL's.

- Arsenic, cadmium, antimony, thallium, and beryllium exceeded the MCL.

- Nickel does not have a MCL.

The MCL is the limit for a constituent in drinking water. The MCL is used to determine the class of landfill required. At 10x MCL, a Class 3 landfill is required. The Salt Disposal Facility (SDF) vaults are permitted as a Class 3 landfill. None of the analyses were greater than 10x the MCL. 
Table 3-2. Saltstone TCLP and UHC Results and Corresponding Regulatory Limits

\begin{tabular}{|c|c|c|c|c|c|}
\hline \multirow[b]{3}{*}{ Analyte } & \multirow{3}{*}{$\begin{array}{l}\text { Results } \\
\text { (mg/L) }\end{array}$} & \multirow[b]{3}{*}{$\mathbf{Q}^{*}$} & \multicolumn{3}{|c|}{ "Regulatory Limits } \\
\hline & & & Toxicity $^{\mathrm{a}}$ & UTS $^{\mathbf{b}}$ & $\mathrm{MCL}^{\mathrm{c}}$ \\
\hline & & & (mg/L) & $\begin{array}{c}\text { Nonwastewater } \\
\text { Standard } \\
\text { (mg/L TCLP) } \\
\end{array}$ & (mg/L) \\
\hline Arsenic & 3.93E-02 & - & 5 & 5 & 0.010 \\
\hline Barium & 7.94E-01 & $\mathrm{J}$ & 100 & 21 & 2 \\
\hline Cadmium & $5.00 \mathrm{E}-03$ & $\mathrm{U}$ & 1 & 0.11 & 0.005 \\
\hline Chromium & $5.00 \mathrm{E}-03$ & $\mathrm{U}$ & 5 & 0.6 & 0.1 \\
\hline Lead & $5.00 \mathrm{E}-03$ & $\mathrm{U}$ & 5 & 0.75 & $0.015^{\mathrm{d}}$ \\
\hline Mercury & $2.0 \mathrm{E}-04$ & $\mathrm{U}$ & 0.2 & 0.025 & 2E-03 \\
\hline Selenium & $1.0 \mathrm{E}-02$ & $\mathrm{U}$ & 1 & 5.7 & 0.05 \\
\hline Silver & $5.00 \mathrm{E}-03$ & $\mathrm{U}$ & 5 & 0.14 & $0.1^{\mathrm{e}}$ \\
\hline Antimony & $2.00 \mathrm{E}-02$ & $\bar{U}$ & - & 1.15 & 0.006 \\
\hline Nickel & $5.00 \mathrm{E}-03$ & $\mathrm{U}$ & - & 11 & - \\
\hline Thallium & $2.00 \mathrm{E}-02$ & $\mathrm{U}$ & - & 0.20 & 2E-03 \\
\hline Beryllium & $5.00 \mathrm{E}-03$ & $\mathrm{U}$ & - & 1.22 & 4E-03 \\
\hline- & $\begin{array}{l}\text { Results } \\
\text { (mg/kg) }\end{array}$ & - & - & $\mathrm{UTS}^{\mathrm{b}}$ (mg/kg) & - \\
\hline Benzene & 1.1E-03 & $\overline{\mathrm{UU}}$ & - & 10 & - \\
\hline Amenable Cyanide & $1.17 \mathrm{E}+00$ & $\mathrm{~J}$ & - & 30 & - \\
\hline Total Cyanide & $1.17 \mathrm{E}+00$ & $\mathrm{~J}$ & - & 590 & - \\
\hline Total Phenol & $9.91 \mathrm{E}-01$ & UJ & - & 6.2 & - \\
\hline
\end{tabular}

- Indicates a location in the table for which an entry would not be appropriate.

${ }^{*} \mathrm{Q}=$ Qualifier Column

$\mathrm{U}=$ Indicates compound was analyzed for, but not detected.

$\mathrm{J}=$ Indicates MS/MSD recoveries were not within specification

a SCDHEC R.61-79.261.24(b) "Characteristic of Toxicity."

b SCDHECR 61-79.268.48 "Universal Treatment Standards."

c SCDHEC R.61-58.5(B) “Maximum Contaminant Levels for Inorganic Chemicals”.

${ }^{\mathrm{d}}$ Lead action level from SCDHEC R.61-58.11.B.

${ }^{\mathrm{e}}$ Secondary drinking water parameter.

\subsection{Analytical Quality Control}

The following subsections include summaries of results from blanks, laboratory control samples, matrix spikes, and matrix spike duplicates. The data package also includes data for calibration verifications, interference checks, and serial dilutions. ${ }^{8}$

\subsubsection{Blanks}

Blank concentrations are given in Table 3-3. In the TCLP Blank, all the analyte concentrations were below the RLs. 
Table 3-3. Method Blanks

\begin{tabular}{||c|c|c|c||}
\hline Analyte & Blank & Units & $\mathrm{Q}$ \\
\hline \hline Arsenic & 10.0 & $\mu \mathrm{g} / \mathrm{L}$ & $\mathrm{U}$ \\
\hline Barium & 5.0 & $\mu \mathrm{g} / \mathrm{L}$ & $\mathrm{U}$ \\
\hline Cadmium & 5.0 & $\mu \mathrm{g} / \mathrm{L}$ & $\mathrm{U}$ \\
\hline Chromium & 5.0 & $\mu \mathrm{g} / \mathrm{L}$ & $\mathrm{U}$ \\
\hline Lead & 5.0 & $\mu \mathrm{g} / \mathrm{L}$ & $\mathrm{U}$ \\
\hline Mercury & 0.20 & $\mu \mathrm{g} / \mathrm{L}$ & $\mathrm{U}$ \\
\hline Selenium & 10.0 & $\mu \mathrm{g} / \mathrm{L}$ & $\mathrm{U}$ \\
\hline Silver & 5.0 & $\mu \mathrm{g} / \mathrm{L}$ & $\mathrm{U}$ \\
\hline Antimony & 20.0 & $\mu \mathrm{g} / \mathrm{L}$ & $\mathrm{U}$ \\
\hline Nickel & 5.0 & $\mu \mathrm{g} / \mathrm{L}$ & $\mathrm{U}$ \\
\hline Thallium & 20.0 & $\mu \mathrm{g} / \mathrm{L}$ & $\mathrm{U}$ \\
\hline Beryllium & 5.0 & $\mu \mathrm{g} / \mathrm{L}$ & $\mathrm{U}$ \\
\hline Benzene & 0.6 & $\mu \mathrm{g} / \mathrm{kg}$ & $\mathrm{U}$ \\
\hline Amenable Cyanide & 0.463 & $\mathrm{mg} / \mathrm{kg}$ & $\mathrm{U}$ \\
\hline Total Cyanide & 0.463 & $\mathrm{mg} / \mathrm{kg}$ & $\mathrm{U}$ \\
\hline Total Phenol & 1.0 & $\mathrm{mg} / \mathrm{kg}$ & $\mathrm{U}$ \\
\hline Q Qualifier Column \\
Indicates compound was analyzed for, but not detected above the RL \\
${ }_{\text {J Indicates MS/MSD recoveries were not within specification }}$
\end{tabular}

\subsubsection{Laboratory Control Samples}

Results from the Laboratory Control Sample (LCS) are given in Table 3-4. The LCS post spike recoveries met USEPA SW-846 acceptance limits for all elements. Laboratory Control Samples are clean aqueous solutions analyzed to assure integrity of the analytical technique exclusive of matrix effects.

Table 3-4. Laboratory Control Samples

\begin{tabular}{||c|c|c|c|c||}
\hline \multirow{2}{*}{ Analyte } & \multicolumn{2}{|c|}{ LCS } & \multirow{2}{*}{ Units } & $\begin{array}{c}\text { Recovery } \\
\text { (\%) }\end{array}$ \\
\cline { 2 - 3 } & True & Recovery & & 97.0 \\
\hline \hline Arsenic & 4000.0 & 3880.99 & $\mu \mathrm{g} / \mathrm{L}$ & 101.1 \\
\hline Barium & 4000.0 & 4042.54 & $\mu \mathrm{g} / \mathrm{L}$ & 96.8 \\
\hline Cadmium & 100.0 & 96.78 & $\mu \mathrm{g} / \mathrm{L}$ & 96.9 \\
\hline Chromium & 400.0 & 387.64 & $\mu \mathrm{g} / \mathrm{L}$ & 96.4 \\
\hline Lead & 1000.0 & 963.57 & $\mu \mathrm{g} / \mathrm{L}$ & 9.1 \\
\hline Mercury & 1.0 & 0.99 & $\mu \mathrm{g} / \mathrm{L}$ & 99.1 \\
\hline Selenium & 4000.0 & 3645.24 & $\mu \mathrm{g} / \mathrm{L}$ & 91.1 \\
\hline Silver & 100.0 & 84.99 & $\mu \mathrm{g} / \mathrm{L}$ & 85.0 \\
\hline Antimony & 1000.0 & 956.08 & $\mu \mathrm{g} / \mathrm{L}$ & 95.6 \\
\hline Nickel & 1000.0 & 947.06 & $\mu \mathrm{g} / \mathrm{L}$ & 94.7 \\
\hline Thallium & 4000.0 & 3827.28 & $\mu \mathrm{g} / \mathrm{L}$ & 95.7 \\
\hline Beryllium & 100.0 & 104.75 & $\mu \mathrm{g} / \mathrm{L}$ & 104.8 \\
\hline Benzene & 10 & 9.3 & $\mu \mathrm{g} / \mathrm{kg}$ & 93 \\
\hline Amenable Cyanide & $\mathrm{NA}$ & $\mathrm{NA}$ & $\mathrm{mg} / \mathrm{kg}$ & $\mathrm{NA}$ \\
\hline Total Cyanide & 67.7 & 49.1 & $\mathrm{mg} / \mathrm{kg}$ & 72.5 \\
\hline Total Phenol & $\mathrm{NA}$ & $\mathrm{NA}$ & $\mathrm{mg} / \mathrm{kg}$ & $\mathrm{NA}$ \\
\hline
\end{tabular}

NA - Not applicable 


\subsubsection{Matrix Spikes}

Results from analysis of the matrix spike (MS) and matrix spike duplicates (MSD) are given in Table 3-5 and Table 3-6, respectfully. These results show that:

- The percent recoveries (\%R) obtained from the MS analyses met the recommended quality control acceptance criteria for percent recoveries, $75-125 \%$ (70 - 130\% for benzene), for all applicable analytes except for barium, silver, phenol and total cyanide. Post digestion spikes were performed for barium and silver and found to be acceptable. Total cyanide and phenol results are discussed in the SWRI report.

- The percent recoveries (\%R) obtained from the MSD analyses met the recommended quality control acceptance criteria for percent recoveries, 75 - 125\% (70 - 130\% for benzene), for all applicable analytes except barium, silver, silver and phenol.

- The RPD(s) between the MS and MSD met the acceptance limits ( 0 - 30\%), except for total cyanide. The result for phenol is "J" flagged due to the MS and MSD recoveries.

- The RPD(s) between the Sample and Sample Duplicate met the acceptance limits except for the cyanide measurements which have been J flagged.

Table 3-5. Matrix Spike and Matrix Spike Duplicate Results

\begin{tabular}{|c|c|c|c|c|c|c|c|c|}
\hline \multirow{2}{*}{ Analyte } & \multirow{2}{*}{ Units } & \multicolumn{3}{|c|}{ Initial Concentration } & \multicolumn{2}{|c|}{ Spiked Sample } & \multicolumn{2}{|c|}{ Recovery (\%) } \\
\hline & & Sample & \multicolumn{2}{|c|}{$\begin{array}{c}\text { Spike } \\
\text { Added }\end{array}$} & Spike & $\begin{array}{c}\text { Spike } \\
\text { Duplicate }\end{array}$ & Spike & $\begin{array}{c}\text { Spike } \\
\text { Duplicate }\end{array}$ \\
\hline Arsenic & $\mu \mathrm{g} / \mathrm{L}$ & 39.38 & \multicolumn{2}{|c|}{2500.00} & 2342.09 & 2382.3 & 92.1 & 93.7 \\
\hline Barium & $\mu \mathrm{g} / \mathrm{L}$ & 793.68 & \multicolumn{2}{|c|}{5000.00} & 4028.62 & 3986.29 & 64.7 & 63.9 \\
\hline Cadmium & $\mu \mathrm{g} / \mathrm{L}$ & 5.0 & \multicolumn{2}{|c|}{500.00} & 418.49 & 427.10 & 83.7 & 85.4 \\
\hline Chromium & $\mu \mathrm{g} / \mathrm{L}$ & 5.0 & \multicolumn{2}{|c|}{1000.00} & 847.71 & 862.79 & 84.8 & 86.3 \\
\hline Lead & $\mu \mathrm{g} / \mathrm{L}$ & 5.0 & \multicolumn{2}{|c|}{2500.00} & 2014.84 & 2052.67 & 80.6 & 82.1 \\
\hline Mercury & $\mu \mathrm{g} / \mathrm{L}$ & 4.5190 & \multicolumn{2}{|c|}{2.00} & 6.1870 & 6.1810 & 83.4 & 83.1 \\
\hline Selenium & $\mu \mathrm{g} / \mathrm{L}$ & 39.99 & \multicolumn{2}{|c|}{2500.00} & 2379.76 & 2472.63 & 93.6 & 97.3 \\
\hline Silver & $\mu \mathrm{g} / \mathrm{L}$ & 5.0 & \multicolumn{2}{|c|}{500.00} & 290.05 & 357.88 & 58.0 & 71.6 \\
\hline Antimony & $\mu \mathrm{g} / \mathrm{L}$ & 20.0 & \multicolumn{2}{|c|}{5000.00} & 4434.34 & 4507.08 & 88.7 & 90.1 \\
\hline Nickel & $\mu \mathrm{g} / \mathrm{L}$ & 7.51 & \multicolumn{2}{|c|}{2500.00} & 2048.53 & 2068.55 & 81.6 & 82.4 \\
\hline Thallium & $\mu g / L$ & 20.0 & \multicolumn{2}{|c|}{2500.00} & 2213.85 & 2254.72 & 88.6 & 90.2 \\
\hline Beryllium & $\mu \mathrm{g} / \mathrm{L}$ & 5.0 & \multicolumn{2}{|c|}{500.00} & 463.14 & 476.44 & 92.6 & 95.3 \\
\hline Benzene & $\mu \mathrm{g} / \mathrm{kg}$ & 1.1 & 18 & 18 & 18 & 18 & 100 & 100 \\
\hline $\begin{array}{c}\text { Amenable } \\
\text { Cyanide }\end{array}$ & $\mathrm{mg} / \mathrm{kg}$ & 1.17 & \multicolumn{2}{|c|}{ NA } & NA & NA & - & - \\
\hline Total Cyanide & mg/kg & 1.17 & 19.4 & 22.6 & 28.2 & 5.28 & 139 & 18.2 \\
\hline Total Phenol $^{\mathrm{J}}$ & $\mathrm{mg} / \mathrm{kg}$ & 0.991 & 18.7 & 24.0 & 0.748 & 0.960 & 0.0 & 0.0 \\
\hline
\end{tabular}

- Indicates a location in the table for which an entry would not be appropriate.

${ }^{\mathrm{J}}$ Matrix spike recovery is outside specified limits 
Table 3-6. Duplicates and Relative Percent Difference

\begin{tabular}{|c|c|c|c|c|c||}
\hline Analyte & Units & Q & $\begin{array}{c}\text { Initial } \\
\text { Sample }\end{array}$ & $\begin{array}{c}\text { Duplicate } \\
\text { Sample }\end{array}$ & RPD \\
\hline \hline Arsenic & $\mu \mathrm{g} / \mathrm{L}$ & - & 39.28 & 46.32 & 16.4 \\
\hline Barium & $\mu \mathrm{g} / \mathrm{L}$ & - & 793.68 & 797.98 & 0.5 \\
\hline Cadmium & $\mu \mathrm{g} / \mathrm{L}$ & $\mathrm{U}$ & 5.0 & 5.0 & - \\
\hline Chromium & $\mu \mathrm{g} / \mathrm{L}$ & $\mathrm{U}$ & 5.0 & 5.0 & - \\
\hline Lead & $\mu \mathrm{g} / \mathrm{L}$ & $\mathrm{U}$ & 5.0 & 5.0 & - \\
\hline Mercury & $\mu \mathrm{g} / \mathrm{L}$ & - & 4.519 & 4.471 & 1.1 \\
\hline Selenium & $\mu \mathrm{g} / \mathrm{L}$ & - & 39.99 & 41.50 & 3.7 \\
\hline Silver & $\mu \mathrm{g} / \mathrm{L}$ & $\mathrm{U}$ & 5.0 & 5.0 & - \\
\hline Antimony & $\mu \mathrm{g} / \mathrm{L}$ & $\mathrm{U}$ & 20.0 & 20.0 & - \\
\hline Nickel & $\mu \mathrm{g} / \mathrm{L}$ & - & 7.51 & 6.52 & 14.1 \\
\hline Thallium & $\mu \mathrm{g} / \mathrm{L}$ & $\mathrm{U}$ & 20.0 & 20.0 & - \\
\hline Beryllium & $\mu \mathrm{g} / \mathrm{L}$ & $\mathrm{U}$ & 5.0 & 5.0 & - \\
\hline Benzene & $\mu \mathrm{g} / \mathrm{kg}$ & $\mathrm{U}$ & 1.1 & - & - \\
\hline $\begin{array}{c}\text { Amenable } \\
\text { Cyanide }{ }^{\mathrm{N}}\end{array}$ & $\mathrm{mg} / \mathrm{kg}$ & $\mathrm{J}$ & 1.17 & 10.9 & 161 \\
\hline Total Cyanide & $\mathrm{mg} / \mathrm{kg}$ & $\mathrm{J}$ & 1.17 & 10.9 & 161 \\
\hline Total Phenol & $\mathrm{mg} / \mathrm{kg}$ & $\mathrm{U}$ & 0.991 & 0.958 & 0 \\
\hline \hline
\end{tabular}

- Indicates a location in the table for which an entry would not be appropriate.

Q Qualifier Column

${ }^{\mathrm{U}}$ Indicates compound was analyzed for, but not detected above the RL

${ }^{\mathrm{J}}$ Indicates RPD is out of specification

\subsubsection{Calibration Information}

- All initial calibration requirements have been met for this sample delivery group (SDG).

- All Contract Required Reporting Limit requirement(s) met the referenced advisory control limits.

- All interference check samples associated with this SDG met the established acceptance criteria.

- All continuing calibration blanks bracketing this batch met the established acceptance criteria.

- All continuing calibration verifications bracketing this SDG met the acceptance criteria. 


\subsection{Conclusions}

Preparation of the 4QCY13 saltstone samples and the subsequent TCLP analyses showed that:

- The saltstone waste form disposed of in the Saltstone Disposal Facility in 4QCY13 was not characteristically hazardous for toxicity.

- The concentrations of the eight RCRA metals and UHCs identified as possible in the saltstone waste form were present at levels below the UTS.

- Analyses met all quality assurance specifications of USEPA SW-846.

The saltstone waste form placed in the Saltstone Disposal Facility in 4QCY13 met the SCHWMR R.61-79.261.24(b) RCRA metals requirements for a nonhazardous waste form. The TCLP leachate concentrations were less than 10x the MCLs in SCDHEC Regulations R.61-107.19, Part I C.

The saltstone waste form placed in the Saltstone Disposal Facility in 4QCY13 met the R.6179.268.48(a) non wastewater treatment standards.

Analyses met all USEPA SW-846 quality assurance requirements. All other limits on holding times, laboratory control sample recoveries, matrix spike recoveries, serial dilution results when applicable, calibration verification, and interference checks were within the quality assurance requirements. 


\subsection{References}

1. Miller, D. H. “4Q13 Saltstone TCLP”, Experiment T8786-00095-01, SRNL E-Notebook (Production); Savannah River National Laboratory, Aiken, SC 29808 (2013).

2. $\quad$ Liner, K.R., "Saltstone Grout Sampling (U)," Savannah River Site, ESH-EPG-2004-00318, 2004.

3. South Carolina Code of Regulations, Chapter 61-Department of Health and Environmental Control.

4. Reigel, M.M., "Task Technical and Quality Assurance Plan for SRNL Support of TCLP Preparation and Analysis for Saltstone-FY2013”, Savannah River National Laboratory, SRNLRP-2012-00859, January 2013.

5. "Toxicity Characteristic Leaching Procedure," EPA SW-846, Procedure 1311.

6. Britt, T.E., "Assessment of Regulated Organics Under 40 CFR Part 268, Section 49, Universal Treatment Standards, Relative to SRS Tank Farm Waste," Savannah River Site, LWO-LWE2007-00052, 2007.

7. Bannochie, C.J., "Tables Containing Results for the Fourth Quarter 2013 Tank 50 WAC Slurry Sample: Chemical and Radionculide Contaminant Results," Savannah River National Laboratory, SRNL-L3100-2014-00016, Revision 2, March 3, 2014.

8. Miller. D.H., "Data Package from Vendor for 4QCY13 Saltstone TCLP Analysis," Savannah River National Laboratory, SRNL-L3100-2014-00056, March 28, 2014. 


\section{Distribution:}

C. J. Bannochie 773-42A

J. M. Bricker 704-30S

T. B. Brown 773-A

N. F. Chapman 766-H

C. K. Chiu 704-30S

J. S. Contardi 766-H

A. D. Cozzi 999-W

S. D. Fink 773-A

K. M. Fox 999-W

E. J. Freed 704-S

C. C. Herman 773-A

P. J. Hill 766- $H$

E. N. Hoffman 999-W

J. F. Iaukea 704-27S

P. R. Jackson 703-46A

V. Jain 766-H

C. A. Langton 773-43A

J. N. Leita 210-S

K. R. Liner 704-S

M. J. Mahoney 705-1C

S. L. Marra 773-A

D. J. Martin 241-152H

D. H. McGuire 999-W

P. W. Norris 704-30S

F. M. Pennebaker 773-42A

M. M. Potvin 704-27S

J.W. Ray 704-S

M. M. Reigel 999-W

L. B. Romanowski 766-H

S. C. Shah 704-30S

C. B. Sherburne 707-7E

F. M. Smith 705-1C

M. E. Smith 704-30S

A. V. Staub 241-119H

B. C. Terry 735-B

S. A. Utlak 704-27S

J. R. Vitali 766- $H$

W. R. Wilmarth 773-A 